\title{
Kontestasi Berita Hoax Pemilu Presiden Tahun 2019 di Media Daring dan Media Sosial
}

\author{
Edwi Arief Sosiawan ${ }^{1}$, Rudi Wibowo \\ 1,2 Program Studi Ilmu Komunikasi, Fakultas Ilmu Sosial dan Ilmu Politik, \\ Universitas Pembangunan Nasional "Veteran" Yogyakarta \\ J1. Babarsari 2, Tambakbayan, Yogyakarta 55281, Indonesia \\ Email: edwias@upnyk.ac.id ${ }^{1 *}$; rudiretno@yahoo.com ${ }^{2}$ \\ *corresponding author
}

\begin{abstract}
Abstrak
Penyebaran informasi berupa berita bohong (hoax) pada pemilihan presiden (pilpres) 2019 meningkat ekskalasinya dibandingkan pilpres 2014. Fenomena berita politik hoax tersebut banyak menyesatkan masyarakat dan digunakan untuk menyerang lawan politik, sehingga selama pilpres 2019 menjadi arena kontestasi antara pasangan calon presiden (capres). Penelitian ini bertujuan untuk mengungkap isi kontestasi berita hoax politik selama pilpres 2019. Metode yang digunakan adalah kuantitatif menggunakan metode analisis isi untuk memberikan gambaran tentang derasnya berita hoax politik yang membahayakan stabilitas politik negara serta memberikan literasi dan kesadaran tentang bahaya dan antisipasi berita hoax. Hasil penelitian ini menyimpulkan bahwa lokus penyebaran berita hoax berada pada media sosial seperti Facebook dan WhatsApp. Berita hoax politik pilpres 2019 bersifat berantai dan memproduksi ulang berita hoax yang pernah ada sebelumnya pada pilpres 2014. Sasaran yang dituju oleh kontestasi berita hoax adalah capres 2019 serta pemerintah pusat. Penajaman berita hoax sangat ampuh dengan menggunakan media sosial dan mengarah pana kebencian antargolongan. Penelitian ini memberikan rekomendasi kepada pemerintah agar aktif mengedukasi mengenai literasi media untuk semua golongan masyarakat agar selektif dalam menerima pesan.

Kata Kunci: Berita Hoax; Media Sosial; Kontestasi Pilpres 2019; Politik
\end{abstract}

\begin{abstract}
The spread of hoax news in the 2019 presidential election increased compared to the 2014 presidential election. The phenomenon of hoax political news is widely misleading to the public and is used to attack political opponents, so during the 2019 presidential election became a contested arena between the spouses of presidential candidates (presidential candidates). The study aims to uncover the content of political hoax news contests during the 2019 presidential election. The method used is quantitative use of content analysis methods to provide an overview of the rush of political hoax news that jeopardizes the political stability of the country as well as provide literacy and awareness of the dangers and anticipation of hoax news. The results of this study concluded that the spread of hoax news is on social media such as Facebook and WhatsApp. News of the 2019 presidential election political hoax is chained and re-produced hoax news that existed before in the 2014 presidential election. The target targeted by hoax news contestants is the 2019 presidential election as well as the central government. The sharpening of hoax news is very potent by using social media and leads to hate speech between groups. This research provides recommendations to the government to actively educate about media literacy for all groups of society to be selective in receiving messages.
\end{abstract} Keywords: Hoax News; Social Media; 2019 Presidential Contest; Political

\section{Pendahuluan}

Hoax saat ini menjadi perbincangan hangat di media massa maupun media sosial karena telah meresahkan publik dengan informasi yang tidak bisa dipastikan kebenarannya. Hoax bermakna sebuah kebohongan atau informasi sesat yang sengaja disamarkan agar terlihat benar, sedangkan berita hoax adalah sebuah publikasi yang terlihat seperti berita faktual tetapi ternyata berisi kebohongan, fitnah, dan tidak memiliki pola yang dapat diidentifikasi (Rasywir \& Purwarianti, 2015). Pada umumnya berita hoax sengaja dibuat untuk menyebarkan propaganda fitnah atau pesan kebencian (hate speech) kepada seseorang atau instansi tertentu.

Banyak masyarakat tertipu oleh berita hoax, berita hoax seolah mampu mengalahkan beritaberita faktual yang dipublikasikan oleh New York 
Times, The Washington Postdan CNN. BuzzFeed. com (BuzzFeed.com diakses 17 Febuari 2017) menengerai bahwa berita hoax ternyata lebih banyak disukai oleh masyarakat. Hal ini terbukti dengan mudahnya hoax disebarluaskan dengan teknik share terutama via media sosial, seperti Instagram, LINE, WhatsApp, Facebook, dan media lainnya (Marwan \& Ahyad, 2016). Kesukaan masyarakat pada berita hoax menurut hasil riset Kementrian Komunikasi dan Informasi (Kominfo) karena media mainstream tidak lagi berpihak kepada masyarakat, media mainstream kurang peka dalam menyerap aspirasi masyarakat luas, serta cenderung menjadi corong para pemilik media (Kominfo.go.id diakses 17 Febuari 2017). Masyarakat kemudian mencari media alternatif untuk pemuasan kebutuhan informasi mereka dengan mencari situs-situs berisi berita-berita hoax tersebut.

Menurutpandangan psikologis, ada dua faktor yang dapat menyebabkan masyarakat cenderung mudah percaya pada berita hoax, yaitu pertama, jika informasi berita hoax tersebut sesuai dengan opini atau sikap yang dimiliki. Misal seseorang memang sudah tidak setuju terhadap kelompok tertentu, produk, atau kebijakan tertentu begitu juga sebaliknya. Ketika ada informasi yang dapat mengafirmasi opini dan sikapnya tersebut maka akan mudah percaya. Sehingga, keinginan untuk melakukan pengecekan kebenaran terlebih dahulu menjadi berkurang.

Kedua, masyarakat mudah percaya pada berita hoax karena terbatasnya pengetahuan atau literasi soal pembacaan dan pemaknaan terhadap berita online. Masyarakat tidak memiliki prior knowledge tentang informasi yang diterima sehingga mudah terpengaruh dan percaya oleh berita hoax (Kompas.com, 23 Januari 2017). Hal ini sejalan dengan John W. Miller dan Michael C. McKenna dalam bukunya World Literacy: How Countries Rank and Why It Matters yang diterbitkan oleh Routledge (2016) (Miller, 2016). Diutarakan literasi masyarakat Indonesia berada diurutan 60 dibanding negara-negara lain.
Fakta dalam kehidupan sehari-hari, hoax sebagai berita membuat tidak seorang pun mampu menghindar terhadap exposure berita hoax. Siapa pun dapat menjadi korban sesatnya informasi berita hoax. Presiden Joko Widodo pun memberikan perhatian khusus terhadap fenomena hoax tersebut dengan imbauan agar media mainstream dan seluruh komponen masyarakat melakukan perlawanan dan pembasmian derasnya berita hoax (Kompas.com, 10 Febuari 2017).

Derasnya berita hoax tersebut oleh Masyarakat Indonesia Anti hoax dinilai sudah tak terkendali lagi. Dalam satu hari terdapat 30 berita hoax yang umumnya berkategori isu politik, kesehatan dan keuangan (Kompas 1 Desember 2016). Kominfo pada Desember 2016 merilis bahwa terdapat 800 ribu situs pembuat hoax dan hate speech di Indonesia, oleh karena itu, dapat dibayangkan dampak serta exposure di rahan publik.

Riset Masyarakat Telematika (Mastel) menyebutkan pada tahun 2016 sebaran berita hoax lebih banyak didominasi oleh berita hoax politik. Dalam riset Mastel tersebut ditemukan fakta bahwa 91,8 persen responden mengaku paling sering menerima konten hoax tentang sosial politik, seperti pemilihan kepala daerah dan pemerintahan. Tidak beda jauh dengan sosial politik, isu SARA berada di posisi kedua dengan angka 88,6 persen. Sedangkan bentuk konten hoax yang paling banyak diterima responden adalah teks sebanyak 62,1 persen. Sementara sisanya dalam bentuk gambar sebanyak 37,5 persen, dan video 0,4 persen. Sedangkan media atau alat yang menyebarkan berita hoax adalah 62,8 persen responden menyatakan mendapatkan berita bohong dari aplikasi pesan; 34,9 persen dari situs dan 8,7 persen dari televisi.

Merujuk pada data riset di atas berita hoax politik menjadi dominan disebarkan kepada masyarakat karena tiga alasan. Pertama, berita hoax merupakan salah satu media yang ampuh untuk digunakan menjatuhkan dan menyerang lawan politik yang efektif. Kedua, pelaku atau pengunggah berita hoax relatif 
sulit untuk diketahui dan dicari keberadaaanya karena bekerja dan bertindak dalam ruang maya atau virtual. Ketiga, berita informasi hoax mampu menyebar dengan cepat serta menjadi viral tanpa harus mengeluarkan biaya dan waktu yang besar dan lama.

Dalam perspektif hukum positif Indonesia, menyebarkan berita hoax walaupun hanya sekadar iseng atau sekadar mendistribusikan (forward) diancam pidana enam tahun dan denda 1 miliar rupiah sebagaimana tercantum dalam Pasal 28 ayat (1) Undang-Undang Informasi dan Transaksi Elektronik. Namun, ternyata ancaman hukuman ini tidak berdampak langsung dengan berkurangnya berita hoax politik yang disebarkan.

Berkaitan dengan pilpres tahun 2019 maka berita hoax menjadi arena kontestasi antar lawan politik yang disebarkan melalui media sosial. Fakta tersebut disampaikan Kominfo yang menyatakan terdapat 62 berita hoax terkait pilpres tahun 2019 (Kami, 2019) dan semuanya mengarah pada kontestasi politik pemilu 2019 khususnya pada pemilihan presiden. Di sisi lain, berita hoax di atas menjadikan pemerintah sebagai petahana menjadi panic. Pada akhirnya memaksa Presiden Joko Widodo diberbagai kesempatan selalu menyinggung masalah hoax dan memerintahkan secara serius aparat kepolisian untuk melakukan tindakan tegas.

Penelitian berita hoax selalu dikaitkan dengan literasi subjek penelitian atau lebih mengacu pada penelitian lapangan yang dilakukan oleh lembaga-lembaga survei. Seperti penelitian Juditha (2018) tentang interaksi komunikasi hoax di media sosial serta antisipasinya yang menghasilkan bahwa pengirim pesan hoax merupakan pihak yang senang dengan pemerintahan Jokowi dan Ahok, dan penerima pesan mendukung pengirim pesan. Penelitian lain yang dilakukan Rahadi (2017) tentang perilaku pengguna dan informasi hoax di media sosial yang menyebutkan bahwa berita hoax dibuat untuk memengaruhi publik terkait isu politik dan SARA, namun beberapa penerima berita kritis dalam menerima berita. Pemerintah sebaiknya berperan aktif dalam meningkatkan literasi masyarakat agar tidak termakan oleh berita hoaks.

Kebaharuan penelitian ini dibanding penelitian sebelumnya, yaitu fakta dan paparan ancaman penyebaran dan derasnya berita hoax politik Pemilu 2019 menjadi dasar pijakan untuk melakukan penelitian ini. Penelitian ini berfokus untuk mengungkap isi kontestasi berita hoax politik selama pilpres 2019.

\section{Hoax}

Kata "hoax" merupakan informasi yang secara sengaja untuk menutupi informasi sebenarnya (Septanto, 2018). Secara historis, kata "hoax" berawal dari "hocus pocus" yang berasal dari bahasa Latin "hoc est corpus" yang artinya "ini adalah tubuh". Kata ini awalnya digunakan oleh penyihir untuk mengklaim kebenaran, padahal sebenarnya mereka sedang berdusta. Hocus digunakan untuk menipu para penyihir dan pesulap zaman dahulu.

Kata "hoax" didefinisikan sebagai tipuan, berasal dari Thomas Ady dalam bukunya Candle in The Dark (1656) atau risalah sifat sihir dan penyihir. Istilah hoax mulai populer berdasarkan film drama Amerika yang dibintangi Richard Gere "The Hoax". Film itu dirilis tahun 2006 yang disutradarai oleh Lasse Hallstrom, penulis skenario William Wheeler yang berdasarkan dari novel dengan judul yang sama karya Clifford Irving pada tahun 1981 (Tattersall, 2018).

Dalam konteks yang lebih luas, hoax bukan hanya sebatas berita palsu saja tetapi tidak lepas dari perjalanan sejarah. Dalam esensinya sejarah mencatat sebuah tradisi Satir Art Hoax (SAH). Satir adalah kritikan, art adalah seni, sedangkan hoax adalah tipuan, manipulasi, mengakali, atau kebohongan (Irving, 2006). Sejarah mencatat SAH dimulai sekitar abad 7. SAH digunakan oleh kritikus untuk mengkritik fenomena kehidupan dalam masyarakat. Tradisi SAH dimainkan oleh seorang kritikus dalam mengkritik sebuah karya seni. 
Satir Art Hoax juga digunakan kritikus dalam mengkritik para akademisi yang banyak menghabiskan waktunya di dalam rumah untuk selalu belajar, sehingga mereka tidak bisa menikmati kehidupan di luar yang lebih luas dan bebas. Hoax mulai populer pada abad 20, melalui perkembangan internet. Pada awalnya Satir Art Hoax, lalu berubah menjadi Satir Hoax, kemudian kian keluar dari jalur menjadi Satir dan/atau Hoax. Jadi, jika merunut pada perjalanan sejarah, definisi hoax tidak sempit hanya berkutat pada masalah "berita palsu". Hoax mencakup suatu perbuatan yang bertujuan untuk menipu/membohongi orang lain dengan cara memanipulasi, mengakali, ataupun menutupi fakta yang sebenarnya. (Irving, 2014).

Perkembangan saat ini, jika mengkitkan hoax dengan teknologi maka terlihat arus penyebaran hoax makin deras. Semakin canggih dan tak terbendung. Gejala hoax makin mewabah sehingga berujung pada fitnah dan maraknya ujaran kebencian. Secara teoritis penyebaran hoax dimulai dari pembuatan dengan bentuk sangat provokatif dan menarik, sehingga orang yang membaca akan membenci atau berkomentar. Padahal, setiap komentar pada links tersebut secara otomatis terhubung pada search engine di media sosial sehingga otomatis crawling dan melakukan record data tersebut. Kemudian hoax tersebut diarahkan agar emosional pembaca yang ingin melakukan share ulang untuk memberitahu teman bahwa "ini hoax". Tindakan ini akan menambah kenaikkan rating postingan hoax karena core mesin pencari pada semua media sosial secara otomatis akan menaikkan rating berita yang paling banyak dilihat dan dikomentari (Potter, 2010).

Seperti halnya situs penipuan, situs hoax sama-sama menutupi identitas pemilik situs seperti kontak dan alamat dengan motif ekonomi. Dengan, faktor identitas sebuah situs jadi rujukan utama untuk mengenali penipuan dan berita bohong di internet. Selain mencari keuntungan, hoax atau cerita bohong sengaja dibuat dengan alasan popularitas tetapi juga dampak munculnya kepanikan masal. Menurut analisa Andrew Potter (2010) beberapa dampak yang ditimbulkan kepada masyarakat dari berita hoax tersebut yaitu: (a) Secara ekonomis, hoax membuang waktu dan uang; membaca hoax dapat menimbulkan kerugian yang tidak sedikit bagi individu dan produktivitas. Setiap orang akan menghabiskan waktu 10 detik saja per hari untuk membaca pesan hoax. (b) Secara kriminal, hoax jadi pengalih isu. Dalam dunia maya, hoax dapat digunakan oleh para penjahat maya atau siber untuk memuluskan aksi ilegal mereka. Umumnya para penjahat siber sering menyebar hoax untuk merusak kerentanan sistem di sebuah layanan internet. (c) Hoax dijadikan ajang penipuan public. Hoax dibuat untuk mencari simpati dan uang. Contoh seperti kabar hoax pembukaan pendaftaran CPNS nasional yang dikirim lewat WhatsApp. (d) Hoax pemicu kepanikan public. Tujuan hoax yang paling banyak diminati oleh si pembuat adalah memicu terjadinya kepanikan publik.

Menurut David Harley (2012) ada beberapa aturan yang dapat digunakan untuk mengidentifikasi informasi hoax secara umum yaitu: Pertama, informasi hoax biasanya memiliki karakteristik surat berantai dengan menyertakan kalimat seperti "Sebarkan ini ke semua orang yang Anda tahu, jika tidak, sesuatu yang tidak menyenangkan akan terjadi”. Kedua, informasi hoax biasanya tidak menyertakan tanggal kejadian atau tidak memiliki tanggal yang realistis atau bisa diverifikasi, misalnya "kemarin" atau "dikeluarkan oleh...". Ketiga, Informasi hoax biasanya tidak memiliki tanggal kedaluwarsa pada peringatan informasi. Meskipun, sebenarnya kehadiran tanggal tersebut juga tidak akan membuktikan apa-apa tetapi dapat menimbulkan efek keresahan yang berkepanjangan. Keempat, tidak ada organisasi yang dapat diidentifikasi yang dikutip sebagai sumber informasi atau menyertakan organisasi tetapi biasanya tidak terkait dengan informasi. 
Mendefinisikan berita ternyata memiliki berbagai sudut pandang di dalamnya. Dengan kata lain, definisi berita tidaklah universal. Dalam buku Here's The News yang dihimpun Paul De Maeseneer (1982) menyatakan bahwa berita adalah informasi baru tentang kejadian yang baru, penting, dan bermakna (signifikan), yang berpengaruh pada para pendengarnya serta relevan dan layak dinikmati oleh mereka. Definisi berita tersebut mengandung unsurunsur yakni baru dan penting, bermakna dan berpengaruh, menyangkut hidup orang banyak, serta relevan dan menarik.

Nimmo (1989) mengartikan berita sebagai proses menegosiasikan laporan yang bermakna tentang kejadian yang mencakup simbolisasi: (1) Kejadian sebagai peristiwa; (2) Peristiwa sebagai sesuatu yang bernilai; dan (3) Peristiwa bernilai berita sebagai kisah berita. Berita dapat diperoleh dari internet, satelit televisi, koran, radio, melalui telepon orang-orang penting (polisi, pemadam kebakaran, dan lain-lain), pengamat berita, radio, masukan dari pekerja di stasiun televisi tersebut (Ted White, 2010).

Berita yang baik dan benar (dipercaya dan obyektif) hanya dapat ditulis apabila didukung fakta dan data yang akurat. Adapun keberhasilan mengumpulkan data dan data yang akurat sangat tergantung pada bagaimana fakta dikumpulkan secara benar. Berbicara mengenai berita politik adalah berbicara mengenai naluri kekuasaan yang dibenarkan secara sosial. Politik dalam arti yang seluas-luasnya adalah dimensi kekuasaan yang mengatur dan mengarahkan kehidupan sosial secara keseluruhan.

Berita politik pada dasarnya sama saja dengan berita yang lainnya dalam hal teknik pengumpulan data dan penulisannya. Namun, berita politik memiliki sisi strategis dibandingkan berita mengenai tema lain. Pemberitaan politik menjadi sarana komunikasi politik dari pihak-pihak yang berkepentingan dengan suatu peristiwa politik. Berita-berita politik selalu menarik perhatian pembaca karena politik pada abad 20 dan abad demokrasi dalam berbgai manifestasinya sekarang akan sangat mempengaruhi kepentingan pribadi-pribadinya di dalam suatu negara. Dalam hubungan ini tidak hanya berita-berita politik internasional menarik perhatian pembaca tetapi berita-berita politik local pun juga menarik perhatian pembaca.

Shoemaker dan Reese (1996) membagi peran media dalam berita politik ke dalam kategori media serta kategori berita politik aktif dan pasif. Kategori media adalah media yang berperan aktif dalam memberitakan berita politik kepada khalayak banyak dalam menentukan isi berita politik dan mengskonstrusikannya. Media secara sadar dan memiliki tujuan tertentu untuk mengarahkan dugaan. Dalam hal ini, sifat media dalam memberitakan politik tidak netral dan berpihak pada konsep media pasif. Sebaliknya, media menyampaikan pesan politik atau sebuah peristiwa apa adanya.

Kategori berita politik yaitu berita yang disampaikan media tidak sengaja untuk mempengaruhi khalayak. Sehingga jika terjadi efek pengaruh, tergantung dari konstruksi khalayak, bukan pada medianya. Tidaklah mudah menentukan apakah berita politik itu mempunyai realitas sosial atau telah direkayasa oleh teknologi yang telah mendekatkan kondisi yang sebenarnya. Dramatisasi tayangan-tayangan baik berita politik maupun iklan politik begitu alami sehingga bagi masyarakat hal ini dianggap sebagai kebenaran. Kepentingan politik yang sanggup membayar untuk spot tayangan menjadikan bias ekonomi politik media tidak bisa dihindari.

Berita politik, sebagai media komunikasi politik, dari sisi pelaku komunikasi baik politikus maupun wartawan sendiri ditujukan bagi pembentukan opini publik (public opinion) dan sikap khalayak terhadap isu politik yang dikomunikasikan. Dalam rangka pembentukan opini publik ini, suatu pemberitaan dilakukan dalam tiga ranah kegiatan sekaligus, yaitu menggunakan simbolsimbol politik (language 
of politic); melaksanakan strategi pengemasan berita (framing strategies); dan melakukan agenda media (agenda setting function).

Berita politik dengan tujuan pembentukan opini menggunakan simbol-simbol politik agar sesuai dengan opini yang hendak disebarkan. Demikian pula strategi pengemasan pesan akan dilakukan dengan seleksi fakta untuk mendukung opini tersebut. Sedangkan fungsi agenda setting adalah penentu bagi media dalam membentuk opini publik di tengah masyarakat (Hamad, 2004). Upaya membangun opini publik ini dengan sendirinya menjadikan pemberitaan politik berpotensi mengalami bias realitas.

\section{Metode Penelitian}

Penelitian ini menggunakan metode kuantitatif dengan objek dalam penelitian ini adalah berita hoax politik yang beredar pada media online selama kurun waktu Agustus 2018 sampai dengan Maret 2019. Alasan pemilihan periodisasi tersebut dikarenakan pada Agustus 2018 dimulai pendaftaran calon presiden untuk pemilu tahun 2019.

Penelitianinimenggunakanmetodeanalisisisi (content analiys) yang merupakan analisis ilmiah tentang isi pesan komunikasi yang mencakup (1) Klasifikasi tanda, (2) Menggunakan kriteria sebagai dasar klasifikasi, (3) Menggunakan teknik analisis tertentu sebagai pembuat prediksi (Setiawan, 1989). Adapun unit analisis dan kategorisasi yang diteliti terlihat pada Tabel 1:

\section{Hasil Penelitian dan Pembahasan \\ Lokus Penyebaran Hoax}

Penyebaran hoax lebih banyak dilakukan melalui platform media sosial $(75 \%)$ dari pada situs media online. Hal ini dikarenakan kemampuan media sosial dalam membentuk jaringan informasi lebih luas dibandingkan dengan situs media berita online yang menuntut keaktifan dari penggunanya. Di sisi lain, justru situs berita online kontentnya dapat diviralkan melalui media sosial seperti Instagram. Sehingga
Tabel 1 Unit-unit analisis dan kategorisasi

\begin{tabular}{lll}
\hline No & \multicolumn{1}{c}{ Unit Analisis } & \multicolumn{1}{c}{ Kategorisasi } \\
\hline 1. & Lokus penyebaran Hoax & 1. Situs Berita Online \\
2. Isi pesan berita hoax & 2. Situs Media Sosial \\
& & 1. Kritikan \\
2. Propaganda \\
3. Identitas penyebar berita & 3. Provokasi \\
& 1. Personal \\
4. Tujuan Berita Politik Hoax & 2. Lembaga \\
& & 3. Organisasi \\
& 1. Opini publik \\
5. Sasaran yang dijadikan Berita & 2. Agenda setting \\
& 3oax & 1. Pemerintah Pusat \\
& & 2. Pemerintah Daerah \\
& & 3. Tokoh politik \\
6 Sifat pesan berita hoax & 4. Partai Politik \\
& & 1. Pesan berantai \\
\end{tabular}

Sumber: Setiawan (1989)

dapat diketahui pola dalam penyebaran berita hoax bersumber dari media sosial. Temuan dalam penelitian ini juga menunjukkan kecenderungan hal yang sama yaitu media sosial menjadi lokus penyebaran berita hoax. Pada kasus ini media sosial yang paling banyak berpengaruh adalah Faceboook dan WhatApp. Keduanya merupakan media populer yang banyak diakses dan digunakan masyarakat.

Salah satu contoh berita hoax yang beredar di media sosial adalah surat dari mantan Presiden RI Susilo Bambang Yudhoyono tentang dukungan putranya kepada Prabowo Subianto untuk menjadi presiden. "Demi bangsa dan negara yang dicintainya, Agus Harimurti Yudhoyono Siap mengabdikan diri untuk Indonesia 2019-2024. Bersama Bapak Prabowo, saya yakin Insya Allah AHY bisa mengurangi kemiskinan di negeri ini. Mari kita sambut pemimpin baru untuk Indonesia yang lebih baik. Cikeas 4 Agustus 2018."

\section{Isi Pesan Berita Hoax}

Keseluruhan berita hoax yang diteliti, hasilnya memiliki kecenderungan isi mengarah pada aksi provokasi (45\%), propaganda (40\%), dan sisanya berisi kritikan. Kecenderungan terhadap dua kategori ini dikarenakan penyebaran berita bohong (hoax) menjadi alat bagi kelompok tertentu untuk mencapai tujuan 


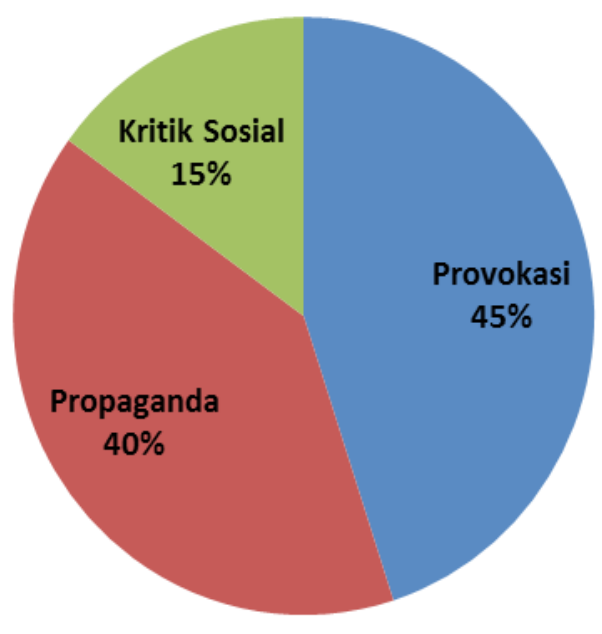

Gambar 1. Isi berita hoax

Sumber: Hasil olahan peneliti (2019)

politik. Hoax tersebut dibuat dan disebarkan secara sistematis, dibuktikan dengan adanya grup-grup percakapan yang memproduksi dan menyebarkan kepada masyarakat luas. Hal ini dapat dilihat pada judul berita yang sering kali memiliki bombastis dan berlebihan untuk memancing pengguna media digital ikut menyebarluaskan dengan membagikan (share) dan menyiarkan (broadcast) ke akun-akun lain, termasuk grup-grup yang berada dalam jaringan mereka. Aktivitas ini sering kali tidak didahului dengan klarifikasi atau pengecekan terhadap kebenaran isi informasi tersebut. Fenomena ini disebut sebagai clicking monkey (Priyambodo , 2013). Clicking Monkeys adalah aktivitas berupa membaca judul berita saja tanpa membaca isi dari berita tersebut. Beberapa ada yang sampai membaca isi dari berita tersebut tetapi lupa untuk melakukan pengecekan silang terhadap berita yang sama pada media lain.

Melalui ramuan judul dan isi berita yang provokatif, ditambah foto sebagai ilustrasi, berita hoax dapat menimbulkan efek menarik (eyecatching) pembaca. Dengan demikian pandangan pembaca diarahkan untuk segera menyimpulkan (jump to conclution) tanpa membaca isi berita secara lengkap, apalagi malakukan cek dan ricek. Judul dan isi berita yang bersifat provokatif dan propaganda umumnya menggunakan tata bahasa yang kontras dengan penggunaan judul yang lazim digunakan dalam media massa. Di sisi lain, isi berita hoax sering mencantumkan sumber yang seolah diambil dari berita media massa mainstream atau daring yang populer seperti Kompas, Koran Tempo, Republika, atau Media Indonesia. Media daring yang sering dicatut namanya adalah detiknews.com dan liputan6. com sebagai situs berita daring yang populer.

Salah satu berita berisikan propaganda adalah postingan video dalam platform Facebook yang menyatakan bahwa organisasi Islam Nahdlatul Ulama mendeklarasikan mendukung calon presiden (capres) dan calon wakil presiden (cawapres) nomor urut 02, Prabowo dan Sandiaga Uno. Padahal, postingan video tersebut tidaklah benar. Video yang beredar tersebut telah diedit dengan narasi yang menyatakan "Mengejutkan! PB NU Akhirnya Resmi Mendukung Prabowo Sandi". Faktanya video tersebut terjadi pada saat Prabowo dan Sandiaga Uno bersilaturahmi dan berkunjung ke kantor Pengurus Besar Nahdlatul Ulama (PBNU) pada 16 Agustus 2018. Tujuan sebenarnya dari kegiatan ini adalah meminta doa restu dalam menghadapi Pilpres 2019.

\section{Identitas Penyebar Berita Hoax}

Identitas penyebar berita hoax sesungguhnya relatif sulit untuk dikenali identitas aslinya. Logika ini berkait dengan hoax yang merupakan berita bohong sehingga umumnya penyebar cenderung mengunakan identitas palsu atau fake identity. Konteks kategori dalam penelitian ini adalah melihat identitas palsu yang digunakan apakah mengatasnamakan organisasi, lembaga ataukah personal. Dari berita hoax yang diteliti, umumnya identitas palsu yang digunakan menggunakan identitas personal. Meskipun begitu, kencenderungannya berimbang dalam penggunaan identitas palsu yaitu $40 \%$ personal, $35 \%$ lembaga dan $25 \%$ organisasi. Fakta dari analisis yang dilakukan juga menemukan adanya identitas personal asli yang digunakan untuk melakukan penyebaran hoax. 
Salah satu contoh unit analisis penggunaan identitas asli dalam berita hoax tersebut adalah cuitan akun@AndiArief_.Akun ini memposting "mohon di cek kabarnya ada 7 kontainer surat suara yg sudah dicoblos di tanjung priok. Supaya tidak fitnah mohon dicek kebenarannya. Karena ini kabar sudah beredar.." Sedangkan berita hoax yang menggunakan identitas palsu organisasi atau lembaga mengungkapkan tentang dukungan kepolisian terhadap pasangan calon No 01. Isi berita tersebut "Kapolsek yg wilayahnya kalah akan dievaluasi oleh kapolda. Ini serius. Jadi tolong dukungannya scra ikhlas dan sadar diri karena kita berjuang utk institusi brarti juga memperjuangkan nasib kita sendiri. Target minimal 60\%. Para kapolsek tolong Agar buat baliho 01 di tiap2 desa/kelurahan. Minimal 1 baliho per desa/kelurahan. Dan kirim laporannya di group ini. Trims."

\section{Tujuan Berita Hoax}

Secara umum berita hoax yang disebarkan saat pilpres tahun 2019 bertujuan politis atau komersial. Para pelaku mereproduksi berita dengan tujuan mencipatkan kondisi politik tertentu serta mendapatkan keuntungan. Hasil analisis berita hoax yang menjadi objek penelitian, dapat dilihat kecenderungan hoax mengarah pada agenda setting dan kepanikan

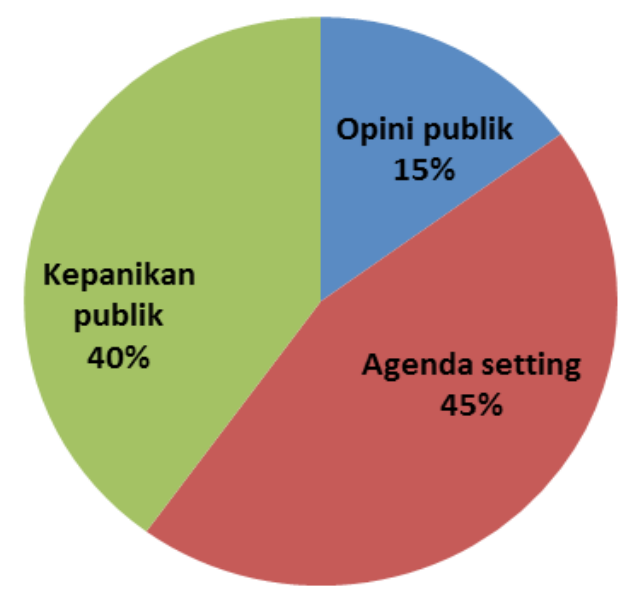

Gambar 2. Tujuan berita hoax Sumber: Hasil olahan peneliti (2019) publik dengan prosentase sebesaar $45 \%$ dan $40 \%$, sedangkan sisanya $5 \%$ merupakan berita hoax yang mengarah pada opini publik.

Berita hoax agenda setting berkarater sebagai berita yang pada prinsipnya membentuk persepsi khalayak tentang apa yang dianggap penting dengan teknik pemilihan dan penonjolan. Berita hoax memberikan penekanan tentang isu dalam narasinya tentang isu yang lebih penting untuk disajikan bagi khalayak. Salah satu contoh adalah berita hoax yang dikirim dari akun akun Facebook (FB) atas nama Arya Setiawan (facebook.com/arya.doang.50702): "Assalamualaikum wr wb. \#COPAS Diberitahukan kepada seluruh relawan Prabowo Sandi agar pada saat pencoblosan berlangsung untuk mengawal \#suratsuara dan ketika \#suratsuara sedang dihitung kita harus memperhatikan dg cermat \#tangan atau \#jari siPenghitung \#suratsuara (bisa jadi \#jari \#tangan siPenghitung melubangi salah satu Paslon). Karena di nomor 1 ada tanda lubang (betul atau tdknya tetap kita harus waspada)yg kemungkinan mudah dibolongin oleh \#jari \#tangan. \#WASPADALAH..!! \#MohonDISHARE sebanyak"nya. \#SalamAkalSehat" (Arya Setiawan, 2019). Contoh untuk berita hoax yang mengarah pada kepanikan publik dapat dilihat pada situs berita daring inibenar.com yang bernarasi sebagai berikut: "Gerakan \#2019GantiPresiden ternyata didukung oleh kaum teroris. Hal itu terbukti dengan ditemukannya sebuah foto seorang perempuan yang membentangkan tulisan \#2019GantiPresiden. "MASIH INGAT KAH SEKELUARGA MELEDAKKAN DIRI BUNUH DIRI DI GEREJA2 DI KOTA SBY KEMARIN??? TERNYATA, IBU INI TRMSUK DLM BARISAN EMAK EMAK NENO WARISMAN!!!"

\section{Sasaran Berita Hoax}

Menjadi lazim ketika berita hoax disasarkan pada lawan politik, namun fakta dalam penelitian ini juga memperlihatkan bahwa pemerintah juga 
menjadi sasaran berita hoax karena salah satu paslon presiden 01 adalah petahana. Komposisi berita hoax dalam unit analisis sasaran berita hoax adalah secara rinci menyasar paling banyak pada tokoh politik yaitu calon presiden itu sendiri yaitu sebesar 68\% sedangkan pemerintah pusat sebesar $21 \%$ dan partai politik sebesar $11 \%$. Salah satu contoh berita hoax yang menyerang capres 01 adalah berita yang bersumber dari akun facebook Dewa Amor yaitu: "Utang Negara Bertambah, Cina Minta Pulau Sumatera dan Jawa Dijual Untuk Bayar Utang RI". Berita hoax tersebut bersumber dari situs berita daring nkri-news-trending. blogspot.com. Berita hoax di ujung tahun 2018 tersebut menyerang posisi Jokowi selaku petahana pilpres 2019 yang dibuat sebagai aksi provokasi melemahkan kampanye pasangan 01 .

Adapun contoh berita hoax yang cenderung menyerang pemerintah adalah kutipan situs berita daring resmi viva.co.id dari akun twitter@m_mirah dengan nama asli Mirah Sumirat yang berisi pernyataan "Hasil laporan anggota di berbagai wilayah Kota Bekasi jumlah TPS ada lebih dari 6000 an dan hampir lebih dari $70 \%$ pasangan 02 menang per tanggal 17 april 2019 pukul. 15.00wib,"

\section{Sifat pesan berita hoax}

Hasil analisis secara statistik diketahui bahwa berita hoax pilpres cenderung merupakan berita berantai yang disebarkan umumnya melalui grup di media sosial ataupun jejaring media sosial. Berita hoax yang berantai tersebut menjadi hal yang perlu dicegah dan waspadai karena umumnya terlanjur menjadi viral sebelum diverfikasi. Beberapa kelompok masyarakat cenderung mempercayai berita tersebut.

Contoh dari berita hoax berantai antara lain tentang perubahan nama Kementerian Agama menjadi Kementerian Urusan Haji Zakat dan Wakaf pada periode kedua pemerintahan Jokowi. Pada informasi tersebut dijelaskan bahwa bukan hanya namanya saja yang diganti, melainkan beberapa peraturan akan turut diganti. Berita hoax tersebut sebenarnya merupakan isu yang pernah ada saat pilpres 2014 dan dimunculkan kembali saat pilpres 2019. Berita yang sama juga terkait berita hoax bahwa Jokowi adalah keturunan Cina yang sebelumnya juga beredar pada pilpres tahun 2014. Kondisi tak jauh berda juga terjadi pada kubu Prabowo yakni isu keluarga yang disebut tidak harmonis, gagal mendidik anak, perceraian dengan Titiek Soeharto. Tujuan penyebaran berita hoax ini untuk mengontraskan pembawaan Prabowo yang terlihat tegas serta membandingkan dengan keluarga Jokowi. Hasil penelitian ini sejalan bahwa berita hoax memang terbukti menciptakan berita bohong untuk menutupi berita yang sebenarnya demi kepentingan sepihak. Hal ini terlihat perlu ketegasan pemerintah dalam mengurangi berita hoax dan mengedukasi masyarakat agar tidak mudah percaya serta selektif dalam melihat berita.

\section{Simpulan}

Media sosial terbukti menajamkan beritaberita hoax selama pilpres 2019 dengan memuat narasi-narasi perseteruan antara Cebong dan Kampret (julukan saling merendahkan bagi para pendukung kedua kubu capres). Bahkan, tersebut justru dijadikan bahan kampanye di antara kedua kubu. Dari 30 berita hoax politik sebagai objek penelitian, capres Jokowi menjadi target terbanyak. Ekskalasi berita hoax juga semakin meningkat dilihat waktu yang dianalisis pada bulan saat mendekati pilpres di tahun 2019. Meskipun demikian, meski berita hoax bertujuan untuk menyerang capres tertentu tetapi terdapat pula berita hoax yang bertujuan menarik atau memperoleh dukungan.

Fakta yang dianalisis memunculkan keprihatinan, mengingat berita hoax pilpres 2019 mendorong penyebaran politik kebencian yang dikhawatirkan bisa mengoyak persaudaraan dan persatuan bangsa, bahkan menjurus ke arah konflik sosial di tengah minimnya tingkat literasi masyarakat. Fakta 
lain yang memprihatinkan adalah produksi berita palsu (fake news) yang dikirim secara berulang-ulang, sehingga dipercaya sebagai suatu kebenaran oleh kelompok masyarakat yang mempercayai informasi palsu tersebut.

Penelitian ini memberikan rekomendasi kepada pemerintah agar memberikan literasi media dan berita melalui media sosial dan digital secara kontinyu terhadap semua golongan masyarakat. Literasi tersebut memiliki materi tentang kewaspadaan terhadap berita yang memiliki judul yang provokatif serta mencek alamat situs sumber berita. Partisipasi masyarakat harus diaktifkan untuk membersihkan konten negatif di media sosial dengan bersama-sama melakukan siskamling digital, melaporkan jika ada konten bermasalah ke Kementerian Kominfo melalui aduankonten.id atau kepolisian.

\section{Daftar Pustaka}

BuzzFeed.com. (2017). https://www.buzzfeed. com/ (Retrived at February 17, 2017).

De Maeseneer, Paul. (1982). Heres The news: A Radio News Manual. Asia-Pacific Institute for Broadcasting Development.

Hamad, Ibnu. (2004). Konstruksi Realitas Politik dalam Media Massa. Jakarta: Granit.

Harley, David. (2012). Common Hoaxes and Chain Letters. USA: ESET LLC.

Irving, Cliford. (2014). The Hoax. New York: Open Road Integrated Media.

Juditha, Christiany. (2018). Interaksi Komunikasi Hoax di Media Sosial serta Antisipasinya. Jurnal Pekommas, 3(1), 31-44.

Kami, Indah Mutiara. (2019). 62 Hoax Pemilu 2019 Teridentifikasi Kominfo, Ini Daftarnya. https://news.detik.com/ berita/d-4368351/62-hoax-pemilu-2019teridentifikasi-kominfo-ini-daftarnya (Retrived at June 25, 2019).

Kominfo.go.id. (2017). https://www.kominfo. go.id/ (Retrived at February 17, 2017).

Marwan, M. R., \& Ahyad, A. (2016). Analisis penyebaran berita hoax di Indonesia. Jurusan Ilmu Komunikasi, Fakultas Ilmu
Komunikasi Universitas Gunadarma.

Miller, John W. r dan Michael C. McKenna. (2016). World Literacy: How Countries Rank and Why It Matters. New York: Routledge.

Nimmo, Dan. (1989). Mediated Political Realities. Aurora il: Longman Pub Group.

Potter, Andrew. (2010). The Authenticity Hoax: How We Get Lost Finding Ourselves. United State: Amazon Pub.

Rahadi, Dedi Rianto. (2017). Perilaku Pengguna dan Informasi Hoax di Media Sosial. Jurnal Manajemen \& Kewirausahaan, 5(1), 58-70. Retrieved from http://jurnal.unmer.ac.id/ index.php/jmdk/article/view/1342

Rasywir, Errissya., \& Purwarianti, Ayu. (2015). Eksperimen pada Sistem Klasifikasi Berita Hoax Berbahasa Indonesia Berbasis Pembelajaran Mesin. Jurnal Cybermatika, 3(2), 1-8. Retrieved from http://cybermatika. stei.itb.ac.id/ojs/index.php/cybermatika/ article/view/133

Septanto, H. (2018). Pengaruh Hoax Dan Ujaran Kebencian Sebuah Cyber Crime Dengan Teknologi Sederhana Di Kehidupan Sosial Masyarakat. Jurnal Kalbiscientia: Jurnal Sains dan Teknologi, 5(2), 157-162.

Setiawan, Bambang. (1989). Metodologi Penelitian Komunikasi. Yogyakarta: Gama Press.

Shoemaker dan Reese. (1996). Mediating the message:Theories of influences on mass media content ( 2 nd ed.). White Plains, N.Y.: Longman.

Sobur, A. (2009). Analisis Teks Media. Bandung: Rosdakarya.

Suprapto, T. (2010). Politik Redaksi Berita. Malang: Pustaka Kaiswara.

Tattersall, Ian, Peter Névraumont, (2018), Hoax: A History of Deception: 5,000 Years of Fakes, Forgeries, and Fallacies, Hachette UK.

White, Ted. (2010). Broadcast News Writing, Reporting, and Producing. Baton Rouge: Focal Press. 